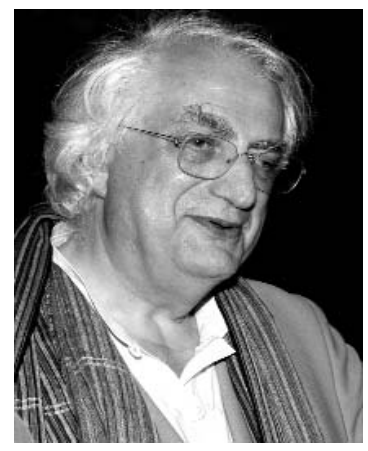

\title{
Entrevista a Bertrand Tavernier
}

El País Semanal, 11 de diciembre de 2005, pág. 20.

\section{¿Cree que ése es el problema del futuro de Europa?}

Veo demasiados políticos que no se toman en serio la cultura. Los niños, por ejemplo, pasan más tiempo frente a la pantalla, ya sea de la televisión o del videojuego, que frente a los profesores. Hay un constante bombardeo de imágenes, y los ministerios de Educación deberían enseñar a los niños a desencriptarlas. Porque los niños de ahora son incapaces de analizar lo que ven, lo que hay detrás de las imágenes. Tengo el ejemplo en mi nieto, que ve cómo le cortan el brazo a alguien y lo que valora es que el efecto especial de la imagen esté bien hecho; no piensa en lo que realmente supone esa imagen, esa situación que se quiere recrear. Los niños de ahora sólo piensan en términos tecnológicos, nunca en conceptos. Y, por tanto, son más fácilmente manipulables.

\section{Es verdad que se impone la espectacularidad de la imagen}

Sí, y si los ministros de Educación no se ocupan de este asunto, creo que se perderá una parte de la batalla de la democracia. Porque mientras hay terroristas islamistas capaces de banalizar las imágenes utilizando vídeos, nosotros somos incapaces de hacer redescubrir una película de Jean Renoir o de Luis Buñuel. Porque los chavales de ahora son incapaces de ver una película en blanco y negro. (En este punto, Bertrand Tavernier está dando pequeños puñetazos de indignación sobre la mesa). ¿̇ué quieren? ¿Qué coloreemos El descendimiento de Alberto Durero? ¿̇ la foto de Cartier- Bresson? No podemos dejar que la ignorancia nos coma el terreno. 